\title{
Zeszyty PRASOZNAWCZE
}

Kraków 2017, T. 60, nr 1 (229), s. 183-200

doi: $10.4467 / 22996362 P Z .17 .014 .6780$

www.ejournals.eu/Zeszyty-Prasoznawcze/

\section{NA POCZĄTKU BYL JAZZ.}

\section{0 lat prasy muzycznej (jazz, rock) w Polsce}

\author{
ARTUR MARIUSZ TRUDZIK \\ Uniwersytet Szczeciński \\ Wydział Filologiczny
}

\section{ABSTRACT \\ In the beginning there was $\mathrm{Jazz} 60$ years of the music (jazz, rock) press in Poland}

The 60th anniversary of Zeszyty Prasoznawcze and Press Research Centre coincides with the debut of the first - in the history of Poland, but also in the whole Eastern bloc - periodical devoted to the de facto banned Western music (jazz, rock), i.e. Jazz (1956), later renamed to Magazyn Muzyczny. Two years later, PR III had its inauguration, and then the Scouting broadcasting station, which for several decades were just a few means of mass communication which could to some extent promote culture, art and especially music from behind the "Iron Curtain". The article is concerned with the description of the beginning and evolution of media dedicated to youth music fans (rock, jazz, pop).

Keywords: music journalism, music media, history and the contemporary Polish press

Adres do korespondencji: Uniwersytet Szczeciński, Wydział Filologiczny, Instytut Polonistyki i Kulturoznawstwa, Zakład Mediów i Komunikowania; ul. Piastów 40B, 71-065 Szczecin; arttru@ interia.pl 
„Z inicjatywy i pod redakcją Józefa Balceraka zaczął się ukazywać magazyn Jazz, co w połączeniu z książką «U brzegów jazzu» Leopolda Tyrmanda rozpoczęło proces wypełniania pustki w ogólnej wiedzy o jazzie".

A. Schmidt, Historia jazzu. Zgiełk i furia. Warszawa 1997, s. 229

\section{Cel, metodologia i zakres badań}

Trwające od kilku lat kompleksowe badania nad dziennikarstwem i mediami muzycznymi o inklinacjach rockowo-jazzowych, mimo iż realizowane koncepcyjnie w szerokiej perspektywie, nadal pozostają dość rozproszone i co zrozumiałe są jeszcze niepełne (Trudzik 2016a). Niniejszy artykuł powinien spełniać dwa zadania. Po pierwsze, wpisywać się w realizowany cykl artykułów naukowych, odtwarzających historię prasy (mediów) muzycznej o tytułowym rodowodzie. Po wtóre, chodziłoby o przeprowadzenie klasycznej analizy prasoznawczej pierwszego okresu wydawania Jazzu (dalej $J$ ).

Najbardziej adekwatnym modelem metodologicznym do tak sformułowanego tematu i postawionego celu, byłoby zintegrowanie dorobku historyczno-komparatystycznego z analizą ilościowo-jakościową (Trudzik 2016b), aczkolwiek niestety nie istnieje materiał porównawczy (jedyny dotyczy Tylko Rocka wydawanego już w III RP) (Trudzik 2014), a ponadto ograniczenia formalne (objętość) wymusiły zawężenie aparatu naukowego (przypisy) tylko do wskazania konkretnych fenomenów (trwałych, kluczowych faktów i zmiennych), a nie pełnych danych statystycznych. Niniejszy tekst objął lata 1956-1963, tj. początkowy okres funkcjonowania $J$ na polskim rynku prasowym. „Narodziny” pierwszego - nie tylko w Polsce, ale i Europie Środkowo-Wschodniej pisma muzycznego (jazz, rock) nie doczekały się jeszcze żadnego opracowania. Ponadto, miesięcznik tylko w tym okresie był rzeczywiście zorientowany wyłącznie na tytułową problematykę, zaś w późniejszych latach zmieniała się wizja pisma, struktura i zawartość. Nastapiło sukcesywne „odchodzenie” od wiodącego rodzaju muzyki na rzecz bardziej przyciagających masowego odbiorcę - rocka i popu. In praxi analiza objęła ogół parametrów krystalizujących prasoznawczą tożsamość periodyku, tj. informacje ogólne, genologię, komunikację wizualną (wraz z reklamą), kontakt z czytelnikami, analizę treści, wstępną ewaluację potencjału ludzkiego.

\section{Wprowadzenie}

Jubileusz 60-lecia zasłużonych dla rozwoju polskiego medioznawstwa Zeszytów Prasoznawczych i Ośrodka Badań Prasoznawczych zbiegł się w czasie z debiutem Jazzu / Magazynu Muzycznego, który okazał się - w kontekście mediów muzycz- 
nych o takim profilu - impulsem dla dalszych jemu podobnych inicjatyw. Dwa lata później miał inaugurację Program III Polskiego Radia (jeszcze nie ogólnokrajowy), a następnie Rozgłośnia Harcerska (choć jej faktyczny debiut to rok 1957 jako Radiostacja Harcerska), które wraz z omawianym miesięcznikiem oraz Jazz Forum i Non Stopem przez kilka dekad były nielicznymi środkami komunikacji masowej upowszechniającymi zachodnią kulturę, sztukę, a zwłaszcza muzykę, jednocześnie promując skutecznie krajowych wykonawców.

Polscy artyści i słuchacze zetknęli się wprawdzie z muzyką jazzową już w dobie II RP, kiedy zaobserwowano, jak ujmuje to Andrzej Schmidt, ,sporadyczne przejawy rosnącego zainteresowania" tym gatunkiem, tym niemniej jego ożywienie przypadło na lata 1945-1948. Niestety stalinizm ,oficjalnie [go - przyp. A.T.] potępił, a praktykowanie i promowanie tego typu muzyki stało się niebezpieczne”, dlatego w ciągu kolejnych sześciu lat trwał „okres katakumb”. Ta negatywna sytuacja zaczęła się zmieniać dopiero od II połowy lat 50.: pojawienie się festiwali (np. w Sopocie jako ,preludium” Jazz Jamboree), wydanie pierwszych płyt (m.in. zespołów Krzysztofa Komedy, Andrzeja Trzaskowskiego, Andrzeja Kurylewicza, Jerzego „Dudusia” Matuszkiewicza i in.) oraz - na co zwracał uwagę Schmidt: ukazanie się $J$ (Schmidt 1997, s. 229).

35-letnie dzieje $J$ trzeba postrzegać w trzech periodach:

1) 1956 - październik 1963 (hegemonia jazzu i sporo muzyki klasycznej; podtytuł Miesięcznik Ilustrowany, który zniknął z winiety w marcu, a ze stopki w sierpniu 1959 r. '; w czerwcu 1960 r. pojawił się dopisek: ,Jedyne pismo jazzowe ukazujące się w państwach demokracji ludowej"2);

2) listopad 1963-1979 (zminimalizowanie roli muzyki poważnej i poszerzenie problematyki jazzowej o rock oraz pop - od numeru 11 (87) z 1963 roku - przez dodanie numerowanej ,wkładki”, a od numeru 11 z 1969 roku podtytułu Rytm i piosenka);

3) 1980-1991 okres już rockowego Magazynu Muzycznego (Trudzik 2015, s. $59-78)$.

\section{Informacje ogólne i struktura}

Założycielem czasopisma i pierwszym redaktorem naczelnym miesięcznika był Józef Balcerak, zajmujący to stanowisko aż 21 lat, tzn. do 1977 r. ${ }^{3}$, przy czym w badanym okresie wspierał go zespół - pod patronatem Rady Okręgowej Zrzeszenia Studentów Polskich w Gdańsku. Cena czasopisma od momentu powstania do 1963 roku nie uległa zmianie i wynosiła 5 zł, oprócz numerów podwójnych: wakacyjnych i styczniowo-lutowych $(10 \mathrm{zl})$. W tych wydaniach automatycznie podwajała się objętość, wzrastając ze standardowych 16 stron do 32 kolumn. Na-

\footnotetext{
$1 J 1969$, nr 7, s. 16.

2 J 1960, nr 6, s. 1.

3 Jego następcą został Janusz Mechanisz.
} 
kład wahał się od 10200 egz. przez 10600 egz. (do lutego 1963 r.), 11962 egz. (tylko w marcu), aż do 15000 egz. - od kwietnia 1963 roku do końca 1962 roku. Siedziba redakcji mieściła się w Gdańsku: ul. Wały Jagiellońskie 1, a druk odbywał się w Gdańskich Zakładach Graficznych. Wydawcą było Gdańskie Wydawnictwo Prasowe RSW „Prasa” (lub Wydawnictwo Prasowe „Ruch”, Warszawa, ul. Nowy Świat 69). W styczniu następnego roku rozpoczął się proces przekształceń - wówczas tylko sugerowany, tzn. w stopce pominięto informacje o redakcji oraz zamieszczono notę o zmianie (na miesiąc) adresu korespondencyjnego (wydawca i administracja) na: Wydawnictwo, administracja i biuro ogłoszeń „Prasa Młodzieżowa” RSW „Prasa”, Warszawa 10, Bagatela 14. Jak się okazało, nie była to przejściowa, lecz dłuższa zmiana, którą oficjalnie podano do wiadomości w numerze lutowym. Od tego wydania, obok redaktora naczelnego, formalnie wyodrębniono stanowisko sekretarza redakcji (określanego też jako ,przedstawiciel w Warszawie"), którym został Adam Sławiński (tylko w tym roku), zaś druk przeniesiono do stolicy: RSW „Prasa”, ul. Smolna 10.

Ponieważ cena $J$ pozostawała jednolita, także koszta prenumeraty były stabilne i wynosiły: 15 zł kwartalnie, 30 zł półrocznie i 60 zł rocznie. Zamówienia i przedpłaty przyjmowały placówki pocztowe i listonosze (do 15 dnia każdego miesiąca) oraz dodatkowo można ich było dokonywać za pośrednictwem konta PKO Przedsiębiorstwa Upowszechniania Prasy i Książki „Ruch” w Gdańsku, ul. Tkacka 9/10. Ponadto zaoferowano sposobność zamawiania tytułu za granicą (21 zł opłata kwartalna, 42 zł półroczna, 84 zł roczna). Zajmowało się tym Przedsiębiorstwo Kolportażu Wydawnictw Zagranicznych „Ruch”, Warszawa, ul. Wilcza 46. Jednocześnie redakcja zaznaczała, iż nie zwraca niezamówionych rysunków, fotografii i rękopisów. Numery archiwalne były dostępne w sklepach prasy antykwarycznej w Warszawie, ul. Wiejska 14 i Puławska 108 (zamówienia spoza stolicy przyjmował dział Sprzedaży Antykwarycznej „Ruchu”"). Rozpowszechniano także numery archiwalne: 3 zł z 1956 roku (tylko 3, 5, 6); 4 zł z 1957; 5 zł z $1958^{5}$. Jeśli chodzi o prenumeratę zagraniczna, warto podkreślić, że redakcja wyrażała satysfakcję, iż np. zmówienia dokonał mieszkaniec Alaski, tytułując tę informację znamiennie: „Prenumerata z krainy Indian i Eskimosów”, bądź uwypuklała fakt, że $J$ był popularny także w Czechosłowacji, gdzie za prenumeratę odpowiadał Polski Ośrodek Kulturalny w Pradze ${ }^{7}$.

Numery 1-18 $J$ ukazały się in folio, natomiast od numeru 20 obowiązujący był format A4 (numer 19 wydano w formacie pośrednim). W czasopiśmie nie ukształtowały się klasyczne działy i rubryki w rozumieniu przemyślanego projektu (matrycy) i sukcesywnego publikowania w kolejnych numerach (lub w ustalonych odstępach czasowych) materiałów, tworzących zamkniętą i spójną tematycznie całość. Warunki takie w zasadzie spełniała jedynie rubryka Od nas do

${ }^{4}$ Stopka redakcyjna, $J$ 1956-1963. Także badania własne autora.

${ }^{5}$ Kompletujemy Jazz, $J$ 1959, nr 9, s. 16.

${ }^{6}$ Prenumerata z krainy Indian i Eskimosów, $J$ 1959, nr 9, s. 3.

7 Uwaga, Czytelnicy w Czechosłowacji!, $J$ 1959, nr 10, s. 16. 
Was (i analogiczna) Od Was do nas oraz elementy ogólne: okładka (czarno-biała, w kolorze lub sepii, drukowana na papierze czarno-białym bądź kolorowym ${ }^{8}$ ), wypełniona najczęściej dużym zdjęciem (od numeru 7-8 z 1958 r. zrezygnowano ze sztywnych okładek, aby nie podnosić ceny ${ }^{9}$ ), z winietą zawierającą logotyp, tytuł, podtytuł (w okresach, kiedy takowy występował) i podstawowe dane (numer, cena, data wydania) oraz spis treści, stopka redakcyjna, prenumerata. Bliższa analiza wykazała jednak, iż można wyodrębnić trwałe składowe pisma, pojawiające się regularnie (cykle artykułów) bądź w pewnych okresach, np. o wspólnym tytule, konkretnym miejscu na łamach czy pisane przez jednego autora: „Ci, na których liczymy”, „Instrumenty i instrumentaliści”, „Z życia klubów”, „Dyskusje”, „Ci, którzy odeszli”, „Kącik wspólnych zainteresowań”, „Korespondencje”, „Korespondencje własne”, oraz elementy takie jak: teksty omawiające koncerty jazzowe w Filharmonii Narodowej, recenzje, nuty, humor i rozrywka, wywiady, recenzje, felietony, grafika (rysunki, reprodukcje, zdjęcia), sylwetki muzyków, reportaże i relacje z koncertów i festiwali w kraju i na świecie).

\section{Różnorodność genologiczna}

W kontekście gatunków dziennikarskich rozdział stanowi w znacznej mierze rozwinięcie tudzież uzupełnienie artykułu poświęconego temu zagadnieniu, ale odnoszącego się do lat późniejszych, zwłaszcza 80. XX w.: „Prasa muzyczna (rock, jazz) do 1989 r. - laboratorium genologiczne” (Trudzik 2017), a zatem nieuniknione wydają się komentarze do ustaleń z niego wynikających oraz przyjęcie analogicznej konwencji prezentacji materiału.

W grupie gatunków informacyjnych zasadniczą dyferencją był fakt, iż w $J$ nie udało się jeszcze stworzyć stałych miejsc dla tych najkrótszych form wypowiedzi, co nie znaczy, że nie podejmowano takich prób - praktycznie we wszystkich numerach występowały wzmianki, notatki, informacje (wraz $\mathrm{z}$ odmianami). Jednak gromadzono je w różnych częściach pisma: Kronika (1-2 strony) ${ }^{10}$, Ciekawostki z kraju, Z kraju, Nowinki ${ }^{11}$ czy Ze świata jazzu (nieco dłuższe formy ${ }^{12}$. Pojawiały się także ko munikaty, np. w kwestii prenumeraty ${ }^{13}$, przeprosiny, choćby za ,poważne opóźnienie niniejszego numeru, spowodowane trudnościami technicznymi”"14, sprostowania ${ }^{15}$, zapowiedzi, np. wizyt znanych osób z kręgu jazzu (prelekcje i spotkania z polskimi muzykami Willisa

\footnotetext{
8 Zob. J 1958, nr 1-5.

9 Redakcja, Do naszych czytelników, Jazz. Magazyn Ilustrowany 1958, nr 7-8, s. 3.

${ }_{10}$ Kronika, J 1959, nr 2, s. 7. Por. tamże, nr 3, s. 3-4.

11 Nowinki, $J$ 1961, nr 10, s. 2 (i in.).

12 Ze świata jazzu, $J 1959$, nr 4, s. 7.

13 Komunikat, $J$ 1958, nr 9, s. 20.

14 Do czytelników, $J$ 1959, nr 3, s. 16.

15 Np.: Errata, J 1960, nr 3, s. 16; Redakcja, Sprostowanie, J 1962, nr 1, s. 14.
} 
Conovera) ${ }^{16}$ czy koncertów, zajawki proponujące najciekawsze materiały z numeru, przegląd prasy zachodniej ${ }^{17}$. Niejednokrotnie informowano o innych tytułach muzycznych (wówczas w zasadzie o jednym na rynku - Ruchu Muzycz$n m^{18}{ }^{18}$. W $J$ nie brakowało sylwetek, m.in. Charlie Mingusa, Charlie „Bird” Parkera, Woody Hermana i in. ${ }^{19}$, również zbiorowych (biografii), np. Jazz Messengers ${ }^{20}$, a także ws pomnieńn ${ }^{21}$. Pojawiały się relacje np. z koncertów czy podkreślające korelacje między jazzem a różnymi sferami życia, kultury i sztu$\mathrm{ki}$, np. malarstwem, filmem ${ }^{22}$. Generalnie informacje nie stanowiły dominującej formy wypowiedzi dziennikarskich, lecz uwzględniając okres wydawania tytułu oraz częstotliwość jego ukazywania się, wypada uznać, iż była ich odpowiednia liczba i spełniały one rygory warsztatowe ${ }^{23}$.

Gatunki publicystyczne zarówno w aspekcie przeznaczanej na nie powierzchni, jak i strategii redakcji były bardziej preferowane aniżeli bieżące, najnowsze wiadomości, zwłaszcza newsy. Przede wszystkim warto zwrócić uwagę na znaczącą rolę artykułów (klasycznych), których rola z biegiem lat w prasie muzycznej raczej malała, np.: o jazzie w... Czechosłowacji, ZSRR etc., czy polemicznych, zamieszczanych w Trybunie dyskusyjnej ${ }^{24}$, np. jednoznaczna i utrzymana $\mathrm{w}$ tonie inkryminacji autora refutacja Adama Sławińskiego na niezbyt eksperckie wypowiedzi i ostry tekst Daniela Passenta o audycjach słowno-muzycznych w PR „Czy Redakcja Polityki nie znalazłaby recenzenta mniej lekkomyślnego [od Passenta - przyp. A.T.]. O ile wiem, aktualny - nie po raz pierwszy przysparzał kłopotów poważnemu pismu"25. Na łamach miesięcznika zainicjowano również trend, który pozostał aktualny do dziś, tj. publikowania tekstów poradnikowych dotyczących sprzętu audio, praktycznych wskazówek dla jego użytkowników, nowinek technicznych, ale i dotyczących historii techniki (zwłaszcza autorstwa mgr. inż. Henryka Cholińskiego, który prowadził specjalistyczny Kącik techniczny - o płytach, słuchawkach, magnetofonach itd. $)^{26}$ tudzież materiałów opracowywanych na podstawie zachodnich pism branżowych $(\text { High Fidelity })^{27}$.

${ }^{16}$ Welcome, Willie!, $J$ 1959, nr 4, s. 5.

${ }^{17}$ F. Lipowicz, Schlagzeug [w:] Przeglądamy prasę fachowa, $J$ 1959, nr 3, s. 8 (i kolejne).

${ }_{18}$ Ruch Muzyczny, $J$ 1959, nr 9, s. 3 (i kolejne).

${ }^{19}$ H. de Wild, Charlie Mingus (thum. i oprac. J.S.), J 1961, nr 2, s. 16 (i kolejne).

20 J. Borkowski, R. Fijałkowski, Jazz Messengers. Biografia sławnego zespołu, J 1959, nr 9, s. 6,16 .

${ }^{21}$ T. Rosenkranz, Moje trzy spotkania..., tamże.

${ }^{22}$ Sier., Jazz i malarstwo, J 1959, nr 9, s. 9 (i dalsze).

${ }^{23}$ Trzeba pamiętać, że gruntowne ilościowe zmiany w proporcjach między publicystyką a informacją nastapiły w prasie muzycznej dopiero w III RP, wraz z rozwojem technologii, powszechnym dostępem do informacji, modernizacją metod pracy redakcji etc. (np. w Tylko Rocku) (Trudzik 2014).

${ }^{24}$ RDK, Off beat [w:] Trybuna dyskusyjna, $J$ 1959, nr 9, s. 11.

${ }^{25}$ A. Sławiński, Dobre rady pana Passenta, $J$ 1959, nr 8, s. 14.

${ }^{26}$ H. Choliński, ,Revival” słuchawek, $J$ 1961, nr 2, s. 10, 15 (i kolejne).

${ }^{27}$ H. Choliński, Hi-Fi. Poszukiwanie złudzenia rzeczywistości, $J$ 1959, nr 8, s. 10 (i dalsze). 
Z kolei tradycją Jazzu, która nie zyskała zbytniej przychylności w innych periodykach muzycznych, była powieść w odcinkach (np. Legenda o Django Reichardtcie ${ }^{28}$ ). Inaczej było w przypadku artykułów w odcinkach (cyklicznych), np. Jana „Ptaszyna” Wróblewskiego ${ }^{29}$, obecnych w większości czasopism muzycznych. Sukcesywnie i umiejętnie rozwijano gatunek nekrologu: kanoniczny $^{30}$, poszerzony o dodatkowe informacje, np. w rubryce Ci, którzy odeszli ${ }^{31}$, lub kontaminowany m.in. ze wspomnieniami, sylwetkami czy biogramami. Niemal niewykształcona została w tamtych latach dy skografia jako wersja kalendarium bądź odrębny gatunek w tym segmencie. Pojawiała się ona sporadycznie, najczęściej w postaci uzupełnienia artykułu i dopiero od 1963 roku wprowadzono rubrykę Polska dyskografia jazzowa, redagowaną przez Marka Cabanowskiego i Henryka Cholińskiego (genologicznie był to jednak de facto po prostu dział recenzji) $)^{32}$.

Spore znaczenie przypisywano reportażom (urozmaicanym fotografiami), opisującym zazwyczaj wrażenia z podróży, oczywiście związanych z jazzem, m.in. Józefa Balceraka „Londyńskie notatki”, „Wieczory paryskie” ${ }^{33}$, Andrzeja Kurylewicza z pobytu w Wiedniu czy Jana „Ptaszyna” Wróblewskiego - „Refleksje francuskie" ${ }^{34}$ (swoje miejsce na łamach posiadali też reportażyści i komentatorzy z Czechosłowacji) ${ }^{35}$. In genere teksty publicystyczne przygotowywali Polacy z kraju i z zagranicy, korespondenci ze świata, chociaż relatywnie dużo było także przedruków. Przeznaczono na nie stałe rubryki: Z zagranicy, Krótko ze świata, Ciekawostki, Kolumna korespondentów zagranicznych (2 strony), Korespondencje własne z zagranicy (jazz m.in. w Holandii, Anglii, Skandynawii, Bułgarii, Czechosłowacji, ZSRR, krajach Beneluksu, RFN, Francji, Kanadzie, USA, ale i... Argentynie). Warto również dodać, że szczególny nacisk kładziono na reportaże z festiwali zagranicznych ${ }^{36}$, zaś niełatwą sztukę felietonu uprawiał m.in. w swojej rubryce pt. Listy z tej ziemi - Lech Terpiłowski ${ }^{37}$ czy „Obserwator” ${ }^{\prime 8}$.

Recenzje ani wtedy, ani nawet kilka dekad później, w latach 80., nie były jeszcze gatunkiem nazbyt eksponowanym w porównaniu ze współczesną prasą

${ }^{28}$ Y. Salgues (thum. J. Grabowska), Legenda o Django Reinhardtcie, $J$ 1959, nr 2, s. 13-14.

29 J. „Ptaszyn” Wróblewski, Ekspresja bije (w Polsce) na alarm [w:] Refleksje z USA, J 1958, nr 12 , s. $4,13$.

${ }^{30}$ (L. Jakubczak), $J 1961$, nr 12, s. 2.

${ }^{31} \mathrm{Ci}$, którzy odeszli, $J 1959$, nr 3, s. 6 (i kolejne).

${ }^{32}$ Niektóre nagrania Browna [w:] A. Szymański, Będziemy pamiętać Clifforda, J 1962, nr 5, s. 7 (i dalsze).

${ }_{33}$ J. Balcerak, Notatki londyńskie 1. ulica, $J$ 1959, nr 2, s. 11-12; tenże, Wieczory paryskie, $J 1960$, nr 3, s. 5, 11 (i dalsze).

${ }^{34}$ A. Kurylewicz, Migawki wiedeńskie, $J$ 1959, nr 8, s. 12-13; J. Ptaszyn, Refleksje francuskie, $J 1961$, nr 1, s. 3.

35 J.P., Jazz v Československu [w:] Strona naszych czechosłowackich korespondentów, $J$ 1960, nr 1, s. 15 .

${ }^{36}$ Krótko ze świata, $J$ 1961, nr 12, s. 6; Ciekawostki, $J$ 1961, nr 1, s. 10 (i dalsze).

${ }^{37}$ Zob. m.in. L. Terpiłowski, Gabinetowa temperatura jazzu [w:] Listy z tej ziemi Lecha Terpiłowskiego, $J 1961$, nr 12, s. 6-7 (i dalsze).

${ }^{38}$ Obserwator, Kult solisty, $J$ 1958, nr 9, s. 10-11. 
muzyczną. Jedną z przyczyn było „zamknięcie” Polski w ścisłych granicach bloku wschodniego, a tym samym ograniczony dostęp do kultury Zachodu i dodatkowo instytucja cenzury, aczkolwiek w Jazzie udawało się relacjonować i opiniować wydarzenia z zagranicy. $Z$ pewnością zaletą ówczesnych recenzji był ich wysoki poziom merytoryczny, a także szeroki wachlarz ocenianych dzieł oraz rodzajów sztuki i kultury (film, teatr, książki, opera, balet i in.), które miały związki z muzyką: Polskie nagrania jazzowe, Film, Muzyka mechaniczna, Wśród książek, Wśród płyt (w nr 5 z 1959 r. podjęto próbę wprowadzenia skali opartej na tzw. ,gwiazdkach”, stosowanej później we wszystkich tytułach) ${ }^{39}$, Wśród nowych nagrań niejazzowych ${ }^{40}$, Muzyka na ekranie, Teatr, Teatr na świecie ${ }^{41}$.

Niebagatelną rolę odgrywały w czasopiśmie gatunki określane przez część genologów jako transgraniczne, nade wszystko list do redakcji i list od redakcji ${ }^{42}$ (przynależne symultanicznie do odrębnej kategorii, tj. komunikacji z czytelnikami). Pojawiały się one w odpowiedziach redakcji, sytuowanych w różnych miejscach: Od nas do Was, Piszą do nas... z kraju, z zagranicy, Kącik wymiany listów, Kącik wspólnych zainteresowań, Listy..., ale też w rubrykach Korespondencje, Korespondencja własna ${ }^{43}$. Od pierwszych numerów pisma skrupulatnie dbano, aby czytelnicy mogli się zapoznać bezpośrednio z poglądami ulubionych, ważnych czy ciekawych postaci, zatem sukcesywnie drukowano wywiady. Bardzo aktywny na tej niwie był Jerzy Radliński, który rozmawiał zarówno z młodymi twórcami w Ci, na których liczymy ${ }^{44}$, jak i najwybitniejszymi muzykami, np. Leonardem Bernsteinem ${ }^{45}$ czy Arturem Rubinsteinem ${ }^{46}$. Trzecią grupe stanowili rozmówcy związani bardziej lub mniej formalnie ze środowiskiem jazzowym, m.in. Paweł Kruk (dyrektor Polskich Nagrań) ${ }^{47}$, kierownik wydziału kultury KC ZMS - Bolesław Kulski ${ }^{48}$, Stefan Rogiński (redaktor działu muzycznego PR) ${ }^{49}$. Osobną kategorię tworzyły rozmowy (w prasie muzycznej de facto terminologicznie tożsame $\mathrm{z}$ wywiadami), zamieszczane w Spotkaniach i rozmowach, m.in. z Jerzym Matuszkiewiczem ${ }^{50}$, Juliette Greco czy Irvingiem Milfredem „Miffem” Mole’em. Typowe dla redakcji było zapraszanie do rozmów cenionych artystów, chociaż reprezentujących inne niż jazz gałęzie sztuki,

$39 * * * * *$ - płyta wybitna, rewelacyjna, $* * * *$ - b. dobra, *** - dobra, ** - przeciętna, * - zła. Zob. A. Trzaskowski, Ellington w Newporcie i „disneyowski Brubeck” [w:] Wśród płyt, J 1959, nr 5, s. $4,7$.

${ }^{40}$ Były to recenzje płyt z muzyką klasyczną, operową, akcydentalnie big-beatową. Zob. A. Szymański, Wśród nowych nagrań niejazzowych, $J$ 1962, nr 2, s. 16.

41 A. Bozet, Czarna Carmen, $J$ 1959, nr 10, s. 12 (i dalsze).

42 Te kwestie zostaną rozwinięte dalej.

43 (red.), Od nas do Was, $J$ 1958, nr 9, s. 18 (i kolejne).

44 AK, Andrzej Dąbrowski [w:] Ci, na których liczymy, J 1958, nr 11, s. 4.

45 R. Waschko, „Muzyka, w której wyrosłem...”, J 1959, nr 8, s. 6, 10.

46 Ak, Mnóstwo „nie” i jedno „tak” mistrza Artura Rubinsteina, $J$ 1960, nr 4, s. 11.

47 Jr, Co słychać w „Polskich Nagraniach”?, J 1959, nr 8, s. 3.

48 J. Radliński, ZMS - mecenat poważny i ambitny, $J$ 1962, nr 5, s. 3, 15.

49 Jr, Jazz w eterze, $J$ 1960, nr 5, s. 11.

$50 \mathrm{Jk}$, Jerzy Milian [w:] Spotkania i rozmowy, J 1959, nr 2, s. 7 (i dalsze). 
jednak inspirowanych w swojej działalności tą muzyką, np. rzeźbiarek - Aliny Ślesińskiej (tutaj pojawiła się forma wywiadu telefonicznego, podobnie jak w przypadku zapisu spotkania z Errollem Garnerem czy przetłumaczonego wywiadu François Postifa z Johnem Coltrane'em, z wyłącznością dla $J$ i Jazz $\left.H o t^{51}\right)$ i Aliny Szapocznikow ${ }^{52}$, już wtedy popularnego aktora - Wojciecha Siemiona $^{53}$ czy Antoniego Krauze (wtedy 21-letniego studenta ASP w Warszawie, po latach znanego reżysera, który zadebiutował na planie filmowym dekadę po tej rozmowie $)^{54}$. Nie tylko w $J$, ale i w innych pismach muzycznych nierzadko pojawiali się jako rozmówcy ówcześni oficjele ${ }^{55}$. Poza tym w periodyku realizowano intrygujące pomysły, np. w związku z koncertami w Polsce światowej sławy dyrygenta - Pawła Kleckiego „o przeprowadzenie wywiadu z wybitnym artystą dla $J$, Redakcja zwróciła się z prośbą do wypróbowanego sympatyka naszego pisma, brata [...] Mieczysława" ${ }^{56}$. Tak jak w przypadku recenzji, dopiero rozwijał się komentarz, zwłaszcza o cechach „plotkarskich”, aczkolwiek pojawiały się „luźniejsze” konstatacje, np. przy wzmiance o Renato Mussolinim - znanym pianiście, komentując jego dorobek, pointowano że w jego przypadku ,jabłko padło daleko od jabłoni, [ponieważ - przyp. A.T.] syn ponurej pamięci «Duce» - nie był spadkobierca jego «idei»».... ${ }^{57}$.

Dokonując reasumpcji gatunków pozadziennikarskich, należy podkreślić ich różnorodność oraz niekwestionowany wkład w uatrakcyjnianie struktury czasopisma, nade wszystko przez eksponowanie elementów graficznych i ,rozrywkowych”, co wpisywało się w linię redakcyjną: „To nie trudne - tak nazwaliśmy dział, do którego wprowadziliśmy łamigłówki" "58. Obok nich odbiorcy otrzymywali: zagadki psychotechniczne, krzyżówki, arytmografy, quizy ${ }^{59}$. Wielokrotnie publikowano życzenia (od redakcji, muzyków, np. Sama Jensena, Humphreya Lytteltona ${ }^{60}$ ), pozdrowienia dla czytelników, np. od wybitnego szwajcarskiego dyrygenta Ernesta Ansermeta, dowcipy ${ }^{61}$, a nawet kalendarz połączony z autoreklamą ${ }^{62}$. Nieszablonowym zabiegiem była rubryka „Twój żółtodziób. Pisemko ludzi, których muzyka znajduje na ulicy", utrzymana w schemacie opowiastek, historyjek i żartów, okraszonych zabawnymi rysunkami. Redakcja tego „biuletynu” była międzynarodowa i skrywała się pod pseudonimami ${ }^{63}$.

${ }^{51}$ J. Rad., Jazz w życiu Aliny Ślesińskiej, J 1960, nr 2, s. 10-11 (i kolejne).

${ }^{52}$ A. Sławiński, Byliśmy z wizytą u wybitnej rzeźbiarki Aliny Szapocznikow, $J$ 1963, nr 5, s. 4.

53 J. Radliński, Wojciech Siemion. Sługa poetów, J 1961, nr 12, s. 4-5.

${ }_{54}$ Jr., Jazz i malarstwo. Plama czy przedmiot?, $J$ 1959, nr 11, s. 5.

${ }_{55}$ Zob. m.in.: C. Kałużny, Cenimy i popieramy, $J$ 1959, nr 1, s. 2, 14.

${ }_{56}$ M. Klecki, Klecki, $J$ 1959, nr 11, s. 10.

${ }^{57}$ Mussolini, $J 1959$, nr 10, s. 13.

${ }^{58}$ To nie trudne, $J 1958$, nr 9, s. 19.

${ }^{59}$ Zob. m.in.: Zagadka psychotechniczna, $J 1959$, nr 2, s. 16 (i dalsze).

${ }^{60} J 1959$, nr 1, s. 11.

${ }^{61}$ Gdzieś-ty fistašku?... [w:] Nie tylko o jazzie, $J$ 1959, nr 4, s. 12.

${ }^{62} J 1960$, nr 1, s. 8-9.

${ }^{63}$ Maria Luisa - Drezno (dziewczynka), Sylwia (Paryż), Ciotka Putch - Londyn, Fistašek - Praga (chłopiec), Kilometr - Mediolan, Papa Caro - Chicago, ja - Kraków. Teksty C.L. i W.Z. 
Wśród gatunków quasi-dziennikarskich znalazły się także: tłumaczenia (np. listu Dave'a Brubecka czy artykułów z prasy zachodniej ${ }^{64}$, impresje dziennikarskie (eseistyczne), np. skompilowane z rozważań nad tekstami Langstona Hughesa „Wielkie morze” i Leopolda Tyrmanda „U brzegów jazzu”, wzbogacone fotką tego pierwszego i drzeworytem Ireny Kuran-Boguckiej ${ }^{65}$. Z kolei cytaty występowały w Wizytówkach muzycznych ${ }^{66}$, zaś fragmenty pierwodruków np. w Almanachu kompozytorów polskich ${ }^{67}$. W pierwszych latach wydawania tytułu występowały ponadto elementy typowe dla prasy repertuarowej, tj. programy radiowe i propozycje najciekawszych audycji, m.in. Godziny jazzu (audycje radiowe Willisa Conovera i Raya Michaela) oraz innych stałych programów o tematyce jazzowej (USA, Europa) ${ }^{68}$. Wreszcie, praktycznie w każdym numerze udostępniano zainteresowanym zapisy nutowe utworów.

\section{Gatunki typowe dla prasy muzycznej będace forma kontaktu z czytelnikami}

Jedną z podstawowych jednostek systematycznych w tej kategorii stanowią podsumowania, które przyjmowały w $J$ kształt artykułów (deskryptywnych), np. Adama Sławińskiego ${ }^{69}$, ankiet (,3 płyty na bezludnej wyspie") $)^{70}$, zestawień pt. „Najlepsi...” (wg zachodnich pism) ${ }^{71}$, konkursów, np. „Jesienny konkurs $J^{\prime \prime}$, pomyślany jako otwarty dla wszystkich utalentowanych w dziedzinach: „kompozycji, poezji, publicystki (reportaż, wywiad, felieton), grafiki, względnie karykatury, fotografiki”. W każdej z nich wyznaczono po trzy nagrody: I. 1000 zł; II. 30-centymetrowa stereofoniczna płyta jazzowa, ofiarowana przez Stana Kentona (Jazz Lift); III. 25-centymetrowa zagraniczna płyta wolnoobrotowa. Dodatkowo gwarantowano publikację wyróżnionych prac (,honorarium wg obowiązujących stawek") $)^{72}$. W 1959 roku pismo przedstawiło wyniki - jak samo określało: „mikro-ankiety”, którą przeprowadził Cabanowski w trakcie krakowskich ,zaduszek jazzowych". Metoda gromadzenia danych polegała na wypełnieniu kwestionariusza przez ok. 50 „muzyków i działaczy jazzowych”, wskazujących najlepszych ich zdaniem w danym roku artystów (w 13 kategoriach: zespół tradycyjny, zespół nowoczesny, trąbka, puzon, klarnet, saksofon tenorowy, saksofon altowy,

Rysunki były autorstwa Cliffa Robertsa i Z. Króla. Zob. „Twój żółtodziób”, nr 1 [w:] J 1959, nr 4, s. 12 (i dalsze).

${ }^{64}$ J. Callwood, Peterson jakiego nie znamy (tłum. J. Grabowska), $J$ 1959, nr 3, s. 4-5.

65 J. Rudke, Kolor duszy. Feelin' blue..., J 1959, nr 11, s. 6.

${ }^{66}$ Wizytówki muzyczne, $J$ 1959, nr 3, s. 8.

${ }^{67}$ A. Trzaskowski, Harmonika i melodyka w jazzie, $J$ 1959, nr 4, s. 10 (i dalsze).

${ }^{68}$ Wykaz niektórych stałych audycji jazzowych, $J 1959, \mathrm{nr} 3$, s. 13.

${ }^{69}$ A. Sławiński, Jazzowa jesień, $J$ 1958, nr, 10, s. 3-4.

${ }^{70}, 3$ płyty na bezludnej wyspie”, $J 1958$, nr 11, s. 3.

${ }^{71}$ Ankiety, ankiety..., $J 1959$, nr 1, s. 3. Por. też: Najpopularniejsi, $J$ 1960, nr 3, s. 6.

72 Jesienny Konkurs Jazzu, J 1961, nr 10, s. 12. 
fortepian, gitara, kontrabas, perkusja, wibrafon, muzyk roku). Redakcja thumaczyła, że uzyskane rezultaty należało „traktować li tylko jako ciekawostkę, ponieważ przeprowadzenie najbardziej miarodajnej ankiety - ogólnopolskiej - było rzeczą niezmiernie trudną - wobec ograniczonego zasięgu działalności zespołów i solistów"73.

Wreszcie w 1961 roku, po wielu latach redakcyjnych deliberacji i głosów napływających z zewnątrz, zdecydowano o wprowadzeniu jednego z najbardziej specyficznych gatunków w mediach muzycznych, tj. plebiscytu-ankiety (z nagrodami dla uczestników), ,wzorowanego na fachowej prasie zagranicznej, mającego na celu wyłonienie najpopularniejszych wykonawców w minionym roku" (z podziałem na kraj i zagranicę). Organizatorzy zauważali, że nie wszyscy słuchacze (czytelnicy) wiedzieli, na kogo oddać swój głos, gdyż wielu z nich miało ograniczony dostęp do ulubionej muzyki. Było to następstwem niewielkiej liczby koncertów, zaledwie pojedynczych audycji o jazzie w radiu, piętrzących się kłopotów w dotarciu do płyt, nielicznych tras obejmujących kilka miast czy braku „stałych [jazzowych - przyp. A.T] koncertów filharmonicznych”, które odbywały się tylko w Warszawie. Naturalnie byli też fani, którzy mieli sposobność bezpośredniego i pełnego ,śledzenia” sytuacji w jazzie. Do uczestnictwa w ankiecie zapraszano obie grupy, a także ,zależało nam na głosach z ZSRR, Czechosłowacji i in. krajów Bloku, będzie to bowiem pierwsza ankieta, dostępna wszystkim miłośnikom jazzu" (w I edycji wyznaczono 21 kategorii, przy czym nie było obowiązku podawania swoich typów w każdej z nich) ${ }^{74}$.

Rozstrzygnięcia podano w kwietniu, dołączając do podsumowania kilka statystyk i uwag. W ustalonym terminie nadesłano 233 odpowiedzi (9 z CSRS i 8 z ZSRR), z czego najwięcej z: Krakowa (43), Warszawy (34), Poznania (15), Szczecina (9), Wrocławia (8), Gliwic (7), Katowic (5). Jurorzy pieczołowicie przestrzegali zasady ,czystości gatunkowej”, która notabene potwierdzała słuszność zaproponowanej na wstępie typologii ewolucji pisma, ponieważ wyrugowano ze zgłoszeń dwóch wykonawców, tj. Franka Sinatrę i Bogusława Wyrobka, uznając, że „reprezentowali oni [...] muzykę rozrywkową". Artystami roku zostali wybrani z ogromną przewagą Zbigniew Namysłowski (kraj) i nieco mniejszą Miles Davis (zagranica). W konkluzji wskazywano na „ogólnie dobre rozeznanie” uczestników, udział muzyków (co nie zdarzało się na Zachodzie) i - co ciekawe, mających zbieżnie gusta $\mathrm{z}$ większością głosujących - partycypację czytelników z Czechosłowacji, którzy do podziału kraj-zagranica dołączyli trzecią kategorię - jazz w CSRS. Zauważono „poczucie humoru” głosujących, np. na perkusistę wybrano „skrzyżowanie Dąbrowskiego z Bartzem”. Poza tym korespondenci

${ }^{73}$ Mikro-ankieta, $J 1959$, nr 11, s. 10.

${ }^{74}$ Były to: muzyk roku, big-band, combo, trąbka, puzon, klarnet, saksofon altowy, saksofon tenorowy, saksofon barytonowy, fortepian, gitara, kontrabas, perkusja, wibrafon, inne instrumenty, wokalista, wokalistka, zespół wokalny, aranżer, kompozytor, nowa gwiazda. Zob. Ankieta Jazzu „Na szczycie", $J$ 1961, nr 2, s. 4. 
proponowali korekty do kolejnej edycji, a pomysłodawcy załączali objaśnienia indywidualne ${ }^{75}$.

W II edycji nie zmienili się „muzycy roku” (Namysłowski i Davis), lecz zwiększyła się liczba uczestników (łącznie 372 odpowiedzi, w tym 35 nieważnych - bez kuponu). Głosujący otrzymali gratis wydawnictwo „Newport Jazz Festival" (dodatkowo nadesłano typy z USA). W konkluzjach stwierdzono, iż nadal nie brakowało żartobliwych odpowiedzi, choć dostrzeżono także nowy symptom ,patriotyzmu lokalnego”, polegający na głosowaniu na wykonawców z miasta, z którego pochodził nadawca listu. Niektóre rubryki były wypełniane „nieco mechanicznie”, albowiem wielu artystów - w tym także jazzowa „czołówka rzadko, a nawet wcale nie trafiała «pod strzechy»”, w zamian ,pod szyldem tzw. «Estrad» nawiedzały wszystkie zakątki kraju pseudojazzowe grupy żerujące na nazwie «jazz»»"

Komunikacja z czytelnikami to głównie rzeczone listy do redakcji ${ }^{77}$ - od czerwca 1959 roku ,wprowadzono system premiowania najciekawszych [...]”, nagradzając autorów książkami i płytami, chociaż przypominano, że podstawą do otrzymania wyróżnienia jest ,jakość, nie ilość”, więc zwyciężyć mogła „nawet korespondencja zawierająca kilka zdań" ${ }^{\prime 78}$. Drugim sposobem zacieśniania więzów między redakcją a czytelnikami oraz między samymi czytelnikami był Kącik zainteresowań, funkcjonujący bezpłatnie dla osób „wymieniających się” płytami, adresami, literaturą etc. („ogłoszenia mające charakter transakcji handlowych były płatne $-5 \mathrm{zł}$ za słowo") $)^{79}$. Podobną misję wyznaczono rubryce Chcą korespondować, za pośrednictwem której fani jazzu nawiązywali wzajemne kontakty $^{80}$. Kolejną inicjatywą był kącik English for the Jazzman, będący reakcją na czasy „rozwijających się pomyślnie kontaktów międzynarodowych” oraz idiomatycznego, „gwarowego języka jazzmanów anglosaskich”. Zaznaczano jednak wyraźnie, iż ten „«kącik» nie będzie prowadzony metodycznie, albowiem rubryka taka nie miała precedensu w żadnej prasie fachowo-muzycznej na świecie", a więc celem było ,podawanie w przybliżeniu (fonetycznie) wymowy wyrazów angielskich bez posługiwania się międzynarodowymi znakami fonetycznymi, gdyż rubryka ta przeznaczona będzie raczej dla tych, którzy byli jeszcze (a może już) z poprawną wymową trochę na «bakier»" ${ }^{81}$. Wychodząc naprzeciw prośbom i oczekiwaniom czytelników, redakcja $J$ zamieściła w 1960 r. aneks dotyczący wszystkich ,artykułów problemowo-źródłowych”, jakie pojawiły się w piśmie ${ }^{82}$.

Spektakularnym, ogólnopolskim przedsięwzięciem zakończonym sukcesem było bezsprzecznie powołanie do życia Klubu Przyjaciół Jazzu (KPJ), którego

75 Pierwsza ankieta czytelników Jazzu, pt. „Jazz na szczycie 1961”, J 1961, nr 4, s. 16.

${ }^{76}$ Wyniki ankiety „Jazz na szczycie 1962”, $J$ 1962, nr 4, s. 16.

77 Od was do nas, $J 1959$, nr 6, s. 2.

${ }_{78}$ Premie za korespondencje!, $J$ 1959, nr 3, s. 15.

${ }^{79}$ W sprawie ogłoszeń w „Kąciku zainteresowań”, $J$ 1961, nr 10, s. 10.

${ }^{80}$ Chcą korespondować, $J 1959, \mathrm{nr} 8$, s. 2.

${ }^{81}$ Jak wymawiać poprawnie? [w:] English for the Jazzmen, $J$ 1961, nr 12, s. 7.

${ }^{82}$ Indeks Jazzu, $J$ 1960, nr 5, s. 6, 10. 
istotą były „,pomoc w pracy indywidualnej i zbiorowej poprzez wypożyczanie: nut (orkiestrówek), książek jazzowych, nagrań płytowych i magnetofonowych, materiałów reklamowych do imprez (fotosy, plakaty etc.), czasopism jazzowych w językach obcych" oraz fachowe doradztwo w postaci „kontaktowania [...] z zagranicznymi zespołami, muzykami i impresariami, zapewnianie $50 \%$ zniżki przy nabywaniu wydawnictw specjalnych $J$, umożliwianie nabycia nowych pozycji z literatury jazzowej natychmiast po ich wydrukowaniu". Członkami mogła być „grupa muzyków-amatorów i innych miłośników jazzu” po opłaceniu do 10 XII 1959 roku pięciu rocznych wartości prenumeraty miesięcznika $(300 \mathrm{zł})$. Równocześnie informowano, że od listopada 1959 roku pismo będzie drukować „dokładniejszy spis książek, nut, taśm, płyt etc., które damy do dyspozycji KPJ"83. Z tej obietnicy redakcja szybko się wywiązała, jednak w lutym 1960 roku, w konsekwencji braku miejsca na łamach pisma, podjęto decyzję o niepublikowaniu ogłoszeń Klubu, a informacje zobligowano się ,przesyłać bezpośrednio do członków" ${ }^{" 4}$.

Ponadto redakcja wyraziła zgodę na przyjęcie funkcji „pośrednika” w akcji Theodore'a R. Greversa polegającej na zbieraniu płyt w USA i wysyłaniu ich do odbiorców w bloku wschodnim, aby ,pomóc uczniom szkół muzycznych i wszystkim miłośnikom jazzu, których pasjonowała ta muzyka" (zamieszczono kupon ${ }^{85}$. Inicjatywę powtórzono pod koniec 1959 roku, a Grevers okazał się dodatkowo inspiracją dla redakcji, która po przesłaniu przez niego (wraz z życzeniami dla czytelników) zdjęcia z żoną i dwójką dzieci (po nim uczynili to m.in. Chet Baker i jego rodzina) podjęła decyzję o stworzeniu nowej, „rodzinnej rubryki”" ${ }^{\prime 6}$.

\section{Komunikacja wizualna}

Rozpatrując zagadnienie komunikacji wizualnej należy uwypuklić kilka elementów, w tym tzw. wkładkę portretową (duże zdjęcie, plakat), przedruki (np. z Esquire $^{87}$ ), fotoreportaże (,Jazz Camping 59”, Włodzimierz Martin) czy rozpoczęcie w połowie 1960 roku druku ,sensacyjnej powieści obrazkowej”, czyli de facto kolejnego komiksu w odcinkach, pt. ,Millenium jazzowe w Polsce" (Jerzy Milian, J. Wróblewski, Jan Zylber) ${ }^{88}$. Trzeba też podkreślić, że z periodykiem od początku byli związani liczni artyści plastycy, rysownicy, twórcy komiksów etc. ${ }^{89}$.

${ }^{83} K P J, J 1959$, nr 10, s. 2. Por. tamże, nr 11, s. 14 (i dalsze).

${ }^{84}$ Od redakcji, $J 1960$, nr 2, s. 11.

${ }^{85} \mathrm{Jazz}$ pośredniczy w bezpłatnym otrzymywaniu zagranicznych płyt wolnoobrotowych, $J 1959$, nr 1 , s. 8 .

${ }^{86}$ Twórca „Jazz Liftu”, $J$ 1960, nr 4, s. 10; Kronika rodzinna, tamże, nr 5, s. 5.

${ }^{87} J 1959$, nr 2, s. 7.

${ }^{88}$ Uwaga!, $J$ 1960, nr 5, s. 5.

${ }^{89}$ Patrz: Potencjał ludzki. 
Natomiast reklamę z oczywistych względów wypada potraktować jedynie jako „ozdobnik”. Pojedyncze przykłady jej wprowadzania to m.in.: materiały reklamowe Centrali Handlu Przemysłu Muzycznego, wody kwiatowej „Lechii” o nazwie Cool Jazz, która podług reklamodawcy ,sprawiłaby Milesowi Davisowi największą przyjemność, gdyby przyjechał do Polski" ${ }^{90}$. Były też autoreklamy w postaci żartów rysunkowy $\mathrm{ch}^{91}$ czy promocji ilustrowanej broszury „Bird. Ptak odleciał...", wydanej przez $J$ (cena $10 \mathrm{zl}$, dla prenumeratorów gratis) ${ }^{92}$. Wykorzystując ten rodzaj komunikacji, „nagłaśniano” też imprezy jazzowe, np. ,Jazz '59” w Hybrydach ${ }^{93}$.

\section{Potencjat ludzki}

Ówczesnych dziennikarzy skupionych wokół periodyku cechowała wszechstronność warsztatowa, którą w późniejszych latach, m.in. ze względów pogłębiającej się specjalizacji, choć zapewne nie tylko $\mathrm{z}$ tego powodu, obserwowano coraz rzadziej. Dziennikarze Jazzu potrafili łączyć np. umiejętność pisania wybornych tekstów z jednoczesną sprawnością translatorską, zdolnościami rysowniczymi, pasją fotograficzną czy operowaniem karykaturą (np. Milian, Jan Wróblewski, Marek Karewicz, Andrzej Trzaskowski, Witold Leszczyński etc.). W „zespole” odpowiedzialnym za stronę graficzną miesięcznika znaleźli się rysownicy, karykaturzyści, malarze, drzeworytnicy (reprodukcje), m.in.: twórca polskiego komiksu - Janusz Christa (seria „Nowy Orlean. Opowieść o Armstrongu”), Julian Żebrowski, Jerzy Skarżyński, Jacek Fedorowicz, Andrzej Krajewski, Jan Kotlik (Czechosłowacja), Kenny Graham (Londyn), J.N. Płużnikow (Kijów), Tadeusz Piskorski, Wiesław Dymny (Kraków), Krzysztof Zagrodzki, Marek Rutkowski, Karol Ferster, Jerzy Krechowicz, Marek Olas, Richard Fremund (Czechosłowacja), Jerzy Milian, Zdzisław Król, Dariusz Kozłowski, Jerzy Skarżyński, Zdzisław Jurkiewicz, Feliks Topolski ${ }^{94}$, ale też... 15-letni Wacław Kisielewski (syn Stefana $)^{95}$ oraz Irena Kuran-Bogucka - znana graficzka i tłumaczka (m.in. Federica Garcii Lorki) ${ }^{96}$. Z kolei fotografią zajmowali się: Marek Karewicz, Krystian Matuszczak, W. Gawor, A. Łoziński, Zygmunt Grabowiecki, Andrzej Dąbrowski, Zbigniew Kosycarz, Włodzimierz Martin, Władysław Romanowski, Andrzej Zborski, Ryszard Żmija, Jerzy Płoński, Wojciech Karolak, Zbigniew Makowski $\mathrm{i}$ in. Poza tym pojawiały się przedruki (Down Beat) oraz zdjęcia niepodpisane ${ }^{97}$.

\footnotetext{
$90 J 1960$, nr 2, s. 14.

91 Ten człowiek jest zadowolony, $J$ 1958, nr 9, s. 8.

$92 J 1959$, nr 2, s. 12.

$93 J 1959$, nr 8, s. 3.

$94 \mathrm{Z}$ teki graficznej Feliksa Topolskiego (Londyn) ofiarowanej bezinteresownie redakcji naszego pisma, $J 1959$, nr 1, s. 16.

95 Wacek gra i rysuje, $J 1959$, nr 2, s. 12.

$96 J 1959$, nr 11, s. 6; $J, 1960$, nr 2, s. 3.

$97 J 1962$, nr 4, s. 7.
} 
W gronie autorów nie sposób nie wymienić choćby znanych krytyków, autorów książek i popularyzatorów muzyki, publicystów, jak Lech Terpiłowski, Jerzy Radliński, Jerzy Rudke, Ryszard Fijałkowski, Jadwiga Grabowska, Ludwik Erhardt, Lucjan Kydryński, A. Schmidt, Roman Waschko, Witold Leszczyński, Witold Pograniczny, Henryk Choliński, Jerzy Rzewuski, Mateusz Święcicki, Marek Cabanowski, Jan Borkowski, Piotr Bartkowski. Byli też i piszący muzycy: klarnecista i klezmer - Lesław Lic, pionierzy polskiego jazzu: kompozytor i pianista - Andrzej Trzaskowski, kompozytorzy, pianiści, trębacze - Andrzej Kurylewicz i Jan „Ptaszyn” Wróblewski, słynny kompozytor - Wojciech Kilar" a także z zachodnich przedstawicieli świata jazzu, m.in. ceniony saksofonista, kompozytor i eseista - Kenneth Graham ${ }^{99}$. Wspierali ich poeci, prozaicy, thumacze: Bogdan Justynowicz, Sławomir Sierecki, Bolesław Fac, Michał Tarasiewicz, Andrzej Brycht ${ }^{100}$ czy Ian McLean ${ }^{101}$. Poza tym, redakcja przybliżała czytelnikom środowisko zachodnich dziennikarzy muzycznych, krytyków, popularyzatorów jazzu czy, jak to wtedy określano, „odkrywców gwiazd jazzu” (z wieloma utrzymywano bliskie kontakty), przeznaczając na to rubrykę Poznajemy wybitnych krytyków i odkrywców gwiazd jazzu. Pierwszym z nich był John Hammond, po nim Hugues Panassié i in. ${ }^{102}$

\section{Zawartość merytoryczna}

W początkowych latach tematyka poszczególnych numerów wpisywała się bezspornie w tytuł miesięcznika, jednak wiele materiałów dotyczyło również muzyki poważnej, stąd nie dziwiły rubryki bądź cykle artykułów: Nie tylko o jazzie, André Hodeira Problemy improwizacji ${ }^{103}$, Kompozytorzy i aranżerzy - Leonarda Feathera ${ }^{104}$, Warsztat kompozytorski (nuty), Instrumenty i instrumentaliści (cykl). Redakcja i współpracownicy ustosunkowywali się do jednego z najsłynniejszych i najbardziej prestiżowych festiwali na świecie, tj. Konkursu im. Fryderyka Chopina $^{105}$, wspominano jubileusz 25. rocznicy śmierci Karola Szymanowskiego, 80 -lecie urodzin Igora Strawińskiego ${ }^{106}$ i pisano o „Warszawskiej Jesieni”"107. Lo-

\footnotetext{
${ }^{98}$ Zob. m.in.: W. Leszczyński, Brenda Lee - „Miss Dynamite” [w:] Kącik fanatyków piosenki, $J$ 1962, nr 6, s. 12 (i kolejne).

${ }^{99}$ K. Graham, Londyn pełen jazzu [w:] Korespondencja własna, $J$ 1959, nr 11, s. 12-13.

100 B. Justynowicz, Swing, $J$ 1958, nr 10, s. 14 (i dalsze).

${ }_{101}$ Próbka poetycka z Londynu, $J$ 1959, nr 7, s. 16. Por. I. McLean, Oh, Didn't he Ramble, tamże.

102 S.J., J. Hammond [w:] Poznajemy wybitnych krytyków i odkrywców gwiazd jazzu, $J$ 1961, nr 10, s. 11 (i kolejne).

${ }^{103} \mathrm{Nr} 11,12$ z 1958, 1, 2 i 3 z 1959.

104 Od L. Feather, Kompozytorzy i aranżerzy, $J 1959$, nr 7, s. 8-9. Por. tamże, nr 9, s. 8-9.

105 I. Wodiczko, A. Sławiński, VI Konkurs, czyli Chopin na punkty, $J$ 1960, nr 4, s. 7.

106 Meloman, Karol Szymanowski [w:] W 25-tą rocznicę śmierci, $J$ 1962, nr 3, s. 14; tenże, Igor Strawiński, $J$ 1962, nr 6, s. 15.

107 J. Balcerak, Ansermet, $J$ 1959, nr 9, s. 5.
} 
giczne było odkrywanie związków łączących klasykę z jazzem, np. przy opisywaniu koncertów jazzowych w filharmoniach ${ }^{108}$. Z radością, a może nawet dumą informowano o tym, iż na „Konserwatorium Leningradzkim zdarzyło się coś niecodziennego; po raz pierwszy na egzaminie przedstawiony został utwór jazzowy" (Kwintetu Eksperymentalnego Liskowicza) ${ }^{109}$.

W materii jazzu warto podkreślić, że miesięcznik prezentował szerszemu odbiorcy czołowych artystów, m.in. Theloniousa Monka, Milesa Davisa, Duke'a Ellingtona, Louisa Armstronga, Johna Coltrane' ${ }^{110}$ etc. Nie zaniedbywano również rocznic związanych z jazzem ${ }^{111}$ i relacjonowano festiwale odbywające się za granicą i w kraju, szczególnie dokładnie analizując jeden z najsłynniejszych i najstarszych w Europie - Jazz Jamboree ${ }^{112}$, poświęcając mu systematycznie coraz więcej uwagi ${ }^{113}$. W latach 50 . na łamach pisma dominował głównie jazz tradycyjny (dixieland, jazz chicagowski, swing), ale tematyka artykułów szybko została wzbogacona o modern jazz i odmiany, które rozwijały się po II wojnie światowej: bebop, cool, hard bob, ale i free jazz. Natomiast o narodzinach jazzu w Polsce pisał np. Jan Borkowski ${ }^{114}$. Uważnie obserwowano sytuację w kraju, koncentrując się m.in. na życiu akademickim i traktując studentów, jako naturalne środowisko krzewienia nowej muzyki (m.in. Ogólnopolski Konkurs Wokalistów Jazzowych, organizowany przez ZSP, PR, Federację Jazz-Klubów Polskich i Sztandar Mło$\left.d y c h^{115}\right)$. Starano się jednocześnie wspierać i konsolidować amatorów, m.in. anonsując i relacjonując ogólnopolski Festiwal Muzyki, Pieśni i Tańca, zorganizowany przez Ministerstwo Kultury i Sztuki z okazji Tysiąclecia Państwa Polskiego ${ }^{116}$.

$\mathrm{Z}$ innych rodzajów muzyki raczej okazjonalnie wspominano np. o muzyce żołnierskiej (15-lecie Wojska Polskiego) ${ }^{117}$, bluesie ${ }^{118}$, a w 1960 roku o beatnikach, tj. kontestatorskim ruchu młodzieży, bezpośrednio poprzedzającym narodziny ruchu hippisów i erę rocka ${ }^{119}$. W 1961 roku lapidarnie informowano o Międzynarodowym Festiwalu Piosenki w Sopocie, choć faktycznie wówczas nie odbywał się w Operze Leśnej, lecz w hali Stoczni Gdańskiej ${ }^{120}$. Rok później ukazała się adnotacja o powstaniu pierwszego w Polsce Klubu Przyjaciół Piosenki (rozrywkowej),

${ }^{108}$ Zob. m.in.: „Zastępca”, VI koncert jazzowy w Filharmonii Narodowej, $J$ 1960, nr 2, s. 5, 11 (i dalsze).

${ }_{109}$ W. Jurczenkow, Jazz wkracza do konserwatorium, $J$ 1960, nr 3, s. 14.

110 Zob. m.in.: H. Thill, Czy „Mnich” spełnił swe posłannictwo?, J 1959, nr 9, s. 4 (i kolejne).

111 A. Sawicki, Charlie Christian - twórca „nowej fali” w grze na gitarze [w:] W 20 rocznicę zgonu, $J$ 1962, nr 4, s. 7, 15 (i kolejne).

112 Zob. m.in.: A. Sławiński, Jaz Jamboree 59, J 1959, nr 10, s. 4-5.

${ }_{113} \mathrm{~Np}$. w $1961 \mathrm{r}$. w nr. 11 były to strony 13-16 i zajawka na okładce.

114 J. Borkowski, Na tropach przedwojennego jazzu w Polsce, $J$ 1962, nr 4, s. 11, 15 (i dalsze).

115 Jazz w życiu kulturalnym studentów, $J$ 1960, nr 1, s. 11 (i dalsze).

116 Amatorskie zespoły jazzowe $\mathrm{z}$ całego kraju wezmą udział $\mathrm{w}$ wielkim ogólnopolskim Festiwalu muzyki, pieśni i tańca, $J 1960$, nr 4, s. 2.

117 L. Lic, Ci, którzy grają na rozkaz (i z upodobania), J 1958, nr 10, s. 6.

118 Pierwszy tekst to: J. Rudke, Kolor duszy. Feelin' blue..., J 1959, nr 11 (41), s. 6 (i kolejne).

119 A. Breza (oprac.), Beat generation, $J$ 1960, nr 1, s. 5, 9.

${ }^{120}$ Rozśpiewane sopockie lato 1961, $J 1961, \mathrm{nr} 7-8$, s. 32. 
mającego za zadanie - „organizację imprez muzycznych, spotkań z popularnymi piosenkarzami, konkursów wokalnych i turniejów młodych talentów" 121 . W tym samym okresie zaczęły się pojawiać - jeszcze nieśmiało - teksty o muzyce popularnej, np. o Johnnym Hallydayu czy Brendzie Lee ${ }^{122}$.

Redakcja wcześnie doceniła rolę natenczas nowego medium, tj. radia, m.in. promując audycje jazzowe w Rozgłośni Harcerskiej, czy rozmawiając z twórcami audycji „30 minut rytmu” - Markiem Gaszyńskim i Witoldem Pogranicznym, z okazji jubileuszu nadania 50. programu ${ }^{123}$. Informowano także o audycjach w PR 1, a od 1962 roku w PR $3^{124}$ i z euforią donoszono o I teleturnieju na temat jazzu ${ }^{125}$. Pismo stało się także koordynatorem przepływu informacji na temat klubów, w których grano jazz, zarówno w największych polskich miastach $^{126}$, jak i w mniejszych ośrodkach ${ }^{127}-\mathrm{z}$ czasem wprowadzono rubrykę Z życia jazz-klubów bądź $\mathrm{Z}$ życia klubowego ${ }^{128}$. W tym przypadku teoria (pisanie) „przeplatała się” z praktyczną aktywnością, ponieważ w 1961 roku „wyruszył do różnych miast Polski przedstawiciel Redakcji [...], aby z bliska «na własne oczy» obejrzeć, w jakich warunkach pracowały środowiska jazzowe, jak również w celu rozbudowania sieci korespondentów terenowych" miesięcznika ${ }^{129}$. Bardzo racjonalne było również animowanie najmłodszych, np. przez włączenie się do dyskusji nad potrzebą wprowadzenia jazzu do lekcji muzyki w szkołach ${ }^{130}$ czy odnoszenie się z atencją do promocji jazzu wśród harcerzy ${ }^{131}$ oraz młodzieży skupionej w $\mathrm{ZMS}^{132}$.

\section{Zakończenie}

Pierwszy w Europie Środkowo-Wschodniej periodyk zajmujący się muzyką jazzową był w perspektywie prasoznawczej urozmaicony, żywo redagowany i utrzymywał wysoki poziom merytoryczny. Jego powstanie i dzieje w początkowym okresie wydawania powinny stanowić punkt wyjścia do analizy ewolucji całego segmentu prasy (mediów) muzycznej (rock, jazz, pop). Nie bez znaczenia pozostaje fakt, iż przemiany w strukturze, ale nade wszystko w zawartości pisma okazały się równocześnie egzemplifikacją kolejnych etapów rozwoju muzyki

\footnotetext{
121 Z.G., Pierwszy w Polsce klub przyjaciół piosenki, J 1962, nr 3, s. 13.

$122 * * *$ (na podstawie „Music Hall”, thum. i oprac. J. Grabowska), Johnny Hallyday [w:] Kącik „fanatyków piosenki”, $J$ 1962, nr 4, s. 13 (i dalsze).

${ }_{123}$ J. Borkowski, „30 minut rytmu” po raz pięćdziesiąty, $J 1960$, nr 4, s. 3.

${ }^{124}$ MS, Jazz w programie Polskiego Radia, $J$ 1962, nr 1, s. 15.

${ }_{125}$ K. Lubowicki, I-szy teleturniej jazzowy, $J$ 1962, nr 4, s. 15.

126 J. Szewczyk, Krakowska mieszanka, $J$ 1960, nr 5, s. 3 (i kolejne).

${ }^{127}$ R. Gajewski, Na tak zwanej prowincji, $J$ 1961, nr 9, s. 3.

${ }_{128}$ Z życia klubowego, $J$ 1961, nr 12, s. 14.

129 W stronę jazzu, $J$ 1961, nr 9, s. 11.

${ }^{130}$ L. Lic., O godziny jazzu z programach szkolnych, $J$ 1961, nr 10, s. 13 (i dalsze).

131 Harcerze proszą o jazz, $J$ 1961, nr 6, s. 3.

132 J. Radliński, ZMS - mecenat..., jw.
} 
rozrywkowej nad Wisłą, ukazując tym samym metamorfozę gustów muzycznych polskiego społeczeństwa.

Nie ulega wątpliwości, że gdyby nie miesięcznik i aktywność jego środowiska na wielu polach (nie tylko dziennikarskim), jazz mógłby przez kolejne lata pozostać w mrokach „okresu katakumb”. Przyjmując optykę recepcji stricte jazzowej, miesięcznik po niecałej dekadzie zaczął „odchodzić” od pierwotnych założeń i wartości, stąd naturalne było, iż jego miejsce i pozycję zajął Jazz Forum. Jednak ten sam fakt można interpretować jako odważną reakcję na szybko wówczas zmieniającą się rzeczywistość kulturową i muzyczną na świecie, ale i w kraju oraz pionierską rolę, jaką pismo odegrało w krzewieniu rocka, powstaniu prasy o takich inklinacjach, a zwłaszcza ,wychowaniu” pokolenia dziennikarzy i publicystów specjalizujących się w tej właśnie odmianie muzyki popularnej.

\section{Bibliografia}

Schmidt A. (1997). Historia jazzu. Zgiełk i furia. Warszawa.

Trudzik A. (2014). Tylko Rock - dzieje pisma oraz rezultaty badań nad miesięcznikiem. Zeszyty Prasoznawcze, nr 3-4, s. 565-591.

Trudzik A. (2015): Rekonstrukcja historii - prasa muzyczna, jako pomijany segment prasy wydawanej oficjalnie w stanie wojennym. W: M. Kaczmarczyk, M. Boczkowska (red.). Media i dziennikarstwo w XX wieku. Studia i szkice (s. 59-78). Sosnowiec.

Trudzik A. (2016a): Dziennikarstwo i media muzyczne. Stan obecny i perspektywy. W: A. Trudzik i M. Parus (red.). Media jako przestrzenie muzyki (s. 14-47). Gdańsk.

Trudzik A. (2016b). Muzyka popularna w prasie polskiej w 2014 r. - modele orientacji metodologicznych opisu mediów muzycznych - ujęcie syntetyczne. W: M. Graszewicz, M. Wszołek (red.). Teorie komunikacji i mediów, t. 9 (s. 19-37). Wrocław.

Trudzik A. (2017). Prasa muzyczna (rock, jazz) do 1989 r. - laboratorium genologiczne. Res Facta Nova, nr 16 (25) (w druku).

\section{STRESZCZENIE}

60 lat temu debiutował pierwszy w historii polski, ale również w całym bloku wschodnim, periodyk poświęcony wówczas de facto zakazanej muzyce zachodniej (jazz, rock), tj. Jazz (1956), przemianowany na Magazyn Muzyczny. Dwa lata później inaugurację miał PR III Polskiego Radia a następnie Rozgłośnia Harcerska, przez kilka dekad będące nielicznymi ośrodkami komunikacji masowej, które mogły w pewnym zakresie propagować kulturę, sztukę, a zwłaszcza muzykę zza żelaznej kurtyny. Artykuł jest próbą opisu zarania i ewolucji mediów przeznaczonych dla fanów muzyki młodzieżowej (rock, jazz, pop).

Słowa kluczowe: dziennikarstwo muzyczne, media muzyczne, historia i współczesność prasy polskiej 